\title{
La transition d'un fait technique
}

Pertinence de l'analyse, exemple des habitations bédouines à Qatar

Anie Montigny-Koslowska

\section{CpenEdition}

\section{Journals}

Édition électronique

URL : https://journals.openedition.org/tc/1020

DOI : $10.4000 /$ tc. 1020

ISSN : 1952-420X

Éditeur

Éditions de l'EHESS

\section{Édition imprimée}

Date de publication : 1 septembre 1983

ISSN : 0248-6016

\section{Référence électronique}

Anie Montigny-Koslowska, «La transition d'un fait technique », Techniques \& Culture [En ligne], 2 | 1983, mis en ligne le 26 janvier 2006, consulté le 29 septembre 2022. URL : http://journals.openedition.org/ tc/1020 ; DOI : https://doi.org/10.4000/tc.1020

Ce document a été généré automatiquement le 29 septembre 2022.

Tous droits réservés 


\section{La transition d'un fait technique}

Pertinence de l'analyse, exemple des habitations bédouines à Qatar

Anie Montigny-Koslowska 